Article

\title{
An Integrative Conceptual Framework for Sustainable Successions in Family Businesses: The Case of Taiwan
}

\author{
Jau Yang Liu \\ Department of Accounting, Chinese Culture University, 55, Hwa-Kang Road, Yang-Ming-Shan, \\ Taipei 11114, Taiwan; liu78705@yahoo.com or lcy13@faculty.pccu.edu.tw; Tel.: +886-937-544-654
}

Received: 24 September 2018; Accepted: 10 October 2018; Published: 12 October 2018

\begin{abstract}
Family businesses have long been one of the mainstream business models in developing countries. The smooth succession of control in family businesses is the key to their sustainable development. However, compared with other companies, succession in family business has demonstrated unique complexity, which also affects the development of the business. The paper is based on a review of the existing literature, starting from the theory of family business succession and combining with grounded theory. After that, we conducted field interviews of experts, coding the key factors affecting succession in family businesses in Taiwan. Finally, we explored the considerations and implications of the succession for inheritance planning. The results of this study show that consideration of succession in family businesses involves a multi-dimensional and complex decision-making process. Among the key considerations, it is found that corporate characteristics, family capital and niche inheritance are the most important without consideration of whether the continuation of the business after succession will be doomed to failure. In addition, the family relationship of affection and trust and commitment between both predecessor and successor are important factors that cannot be ignored, especially in a rapidly changing competitive market environment.
\end{abstract}

Keywords: family business; succession plan; corporate characteristics; family capital; niche inheritance; multi-attribute decision model (MADM); social sustainability

\section{Introduction}

In a family business, it is not a simple matter for the successor to successfully take over the heavy responsibility of leadership from the predecessor to ensure that the company continues to develop while maintaining harmony among its various family members and stakeholders [1]. For family businesses, succession is not simply the passing of leadership on to the next generation, but also includes considerations of ownership structure, management rights and control rights, governance structure, family interests and the future business direction of the company [2-4]. In other words, leadership succession has certain elements of complexity, and its effects are relatively extensive.

Although some family-owned enterprises have developed into listed companies through entry into the capital market, with the new trend of the enterprise internationalization and the introduction of professional management teams, whether the family business can still maintain its original business model and continue to preserve the momentum for future growth is still unclear. After decades of evolution of Taiwanese family businesses, many are now facing serious issues with generational alternation, corporate transformation and the continuation of family power and freedom from disintegration. In this narrative, the first generation of family businesses is not only strongly reliant on the founders' leadership, but also dependent on the founder's network of relationships and knowledge 
base. In this type of situation, a lack of inheritance planning is likely to lead to the loss of these key management resources [5].

In terms of succession, family business owners usually only consider the relationships and configuration of the family and corporate equity. They may lack understanding and analysis of other important factors affecting family business succession, such as changes in the business environment, company characteristics, family tradition and the status of niche inheritance [6]. Despite the consensus among academics on the importance and multidimensional nature of inheritance, scholars have failed to reach any consensus on the components or dimensions of the succession that are most important.

In short, it is obvious that the family business's inheritance decision has clearly not been solved in practice or in theory. The inheritance decisions of family businesses are still unable to be planned. In addition, many past discussions about family heritage appearing in the literature have been descriptive case studies, and few have used qualitative data. Furthermore, there has been a lack of quantitative data related to the inheritance variables in family inheritance, and an even greater lack of integrated research. Therefore, to compensate for this gap in the literature, our research goal is to develop a comprehensive conceptual framework for full consideration of all the potential factors affecting family business inheritance needed to avoid failure in the future and improve the efficiency of inheritance decision-making.

After a review of the existing literature, along with the application of grounded theory, we conduct field interviews to find the key factors affecting family business inheritance, and then employ the decision-making trial and evaluation laboratory method (DEMATEL) and the analytic network process (ANP) of multi-criteria decision-making method to construct the influential network relation maps (INRM) for a systematic performance improvement and to find the weights and priorities of the inheritance factors. Finally, in order to grasp the direction of family inheritance and succession more accurately, the VIKOR (VlseKriterijumska Optimizacija I Kompromisno Resenje) method is integrated for analysis of the positive-ideal solution and negative-ideal solution.

This methodology allows the evaluation of the current situation, to find the key factors that are most important and to make comparisons between candidate solutions and the ideal solution. The results of this study can be used as a reference for family business succession planning. It is hoped that the results will not only be useful in understanding the decision-making environment of the family business and the strategic goals of inheritance and succession, but also contribute to a better theoretical understanding of sustainable family business management, the effects of inheritance of family businesses and the formulation of strategic development.

\section{Literature Review}

The succession and governance of family businesses is a highly valued research topic that covers a wide range of aspects. This study can be divided into two parts: in the first section, we discuss family business development and governance type; the second section contains an analysis of the key influential factors in family business succession.

\subsection{Family Business Development, Governance and Succession}

The succession of authority in family businesses has been studied by the academic community since the 1950s, with considerable attention being paid to family business related issues in Asian countries in recent years. Simply put, a family business is a business run by a group of individuals with a blood relationship [7]. Although the definitions of family businesses might be different, the judgment as to what is a family business is based on ownership, management and control. Here, a family business is defined as one run by an entrepreneur or a family member (spouse, children or their children) who holds more than half of the voting rights in the company, with at least one family member holding a management position in the company [8]. In the case of a publicly-held company, the entrepreneur or their family members should hold at least $25 \%$ of the shares, with at least one family member serving on the board of directors. In the past, the academic definition of a family 
business has differed depending on whether family members hold seats on the board of directors and on their control of shareholding and voting rights [9].

Handler's [10] study of family businesses suggests that aggressive entrepreneurship and strong family cohesion are major factors in the success of family businesses. However, the unique characteristics of the family business may make its corporate governance, management characteristics and corporate governance environment inferior to that of non-family businesses. Longenecker and Schoen [11] pointed out that the enterprise succession process is dynamic and comprises a combination of activities related to inheritance within the context of a specific period of time. In the study of family business, family inheritance is usually regarded as a process of power transfer, which is not simply equivalent to legal inheritance. Recently, Nuñez-Cacho et al. [12] emphasized that environmental issues must also be taken into consideration as they are increasingly important to sustainability, hence the development of theories of functionality, ecology and development.

In short, the issue of succession in a family business is very complex [13-15]. Past models of the process of inheritance of family businesses can be divided into three types: evolutionary process models, family life cycle perspective models and psychological perspective models with more studies focusing on the study of the inheritance evolution process models, emphasizing the process of inheritance. Among them, Longenecker and Schoen [11] broke down the succession process into seven stages, three of which would take place before the successor actually enters the business as a full-time employee. Handler [10] summarized the inheritance process as comprised of three phases of interconnection. In addition, a variety of succession models have been built based on the different perspectives of entrepreneurs, successors and family businesses. For example, Churchill and Hatten [16] used a life cycle approach to describe the succession process between father and son in a family firm. They divided the life cycle of an enterprise into: (1) the stage of owner-management; (2) the stage of training and development; (3) the partnership stage between father and son; and (4) the stage of power transfer.

In addition to the above, Nuñez-Cacho et al. [12] further noted that the very nature of the family company positions it well to face the challenges posed the new environmental scenarios. They employed the principles of a circular economy to design a sustainable model, which shows family businesses' responses to changes in the environment. O'Leary and Swaffin-Smith [17] also proposed an organic model for depicting the transitional nature of family businesses that reflect the dynamics involved when both business and family issues are intermingled. The model depicts a quadrant of family business types (personal, livelihoods, bank and heritage) that overlap to form transition zones between those four principal states of being.

In the inheritance of family businesses, sanguinity is still the key factor and primary consideration [18]. Father-to-son succession is the mainstream inheritance model in the early stage of family business development, and it is still a common way for family businesses to pass from generation to generation [19]. However, from the perspective of history or inheritance theory, when family businesses grow or expand in size, family members will face challenges such as whether they can afford to preserve the family mission and whether they have the will and ability to continue the inheritance. Therefore, the family business's choice of successors might not be limited to family members.

With the rapid development of the economy in Asia, the expansion of family businesses and the development of closer relationships between the enterprise and society, family boundaries are easily broken in the process of inheritance of the family business. The family trust is another emerging enterprise inheritance model for today's family businesses. This model includes the designing of a trust to safeguard the management, inheritance and protection of family wealth. The beneficiaries are generally family members. The main purpose of its establishment is to solve the problem of inheritance when passing property across generations and to achieve an effective and stable transfer of family equity and management for a unique inheritance model [20]. According to relevant research, modern family trusts tend to be more involved with public interests, while still paying attention to 
family interests. Modern trusts also include considerations of family and corporate governance, equity management and the distribution of beneficiary rights.

\subsection{Analysis of the Key Factors Influencing Family Business Inheritance}

Since the 1950s, the academic community has studied family businesses. However, although intergenerational inheritance is a core issue in the family business field, no unified conclusions have been reached. Lansberg and Astrachan [14] pointed out that inheritance plans usually include the preparations necessary to ensure family harmony and business continuity and must take into account the future needs of businesses and families. Therefore, in the process of inheritance planning factors such as corporate characteristics, governance patterns and management models, family relationships and inheritance conditions should be considered.

Of course, the assessment framework may also include other factors related to inheritance, such as: industry characteristics, mechanisms for dealing with inheritance and the trust of the predecessor and the willingness and commitment of the successor [21]. To obtain insights into family business inheritance, we gained information from three different sources: the academic literature, the heir's recommended attributes and interviews with predecessors about their expectations of their successors or their perceptions of successor requirements.

Among them, the academic literature mainly comes from the online Web of Science Core Collection (WSCC) database and the ScienceDirect OnSite (SDOS) database. The keywords of the review were searched on the theme of "inheritance," "succession," and "family business" in the period 1979-2018. There are 42 major journals from all the publications identified (121) including family business research (19), entrepreneur theory and practice (8) and sustainability (4). In addition, the main interviewees were entrepreneurs enrolled in a Taiwanese SME Family Business Inheritance Training Course. The content obtained from the interviews was combined with grounded theory and then used to encode the factors affecting inheritance decision-making.

The key considerations of inheritance and succession of the family business after analysis show a multi-dimensional relationship and are interrelated with each other. It is difficult to judge the superiority or the inferiority of the various factors. Moreover, the considerations of business owners are not only complicated, but also various factors of inheritance considerations are very meaningful and logical. The overall considerations are shown in Table 1 . They can be divided into five major facets and 13 metrics.

Table 1. The dimensions and criteria for family business transferring and succession.

\begin{tabular}{|c|c|c|c|}
\hline Dimension & Criteria & Description & References \\
\hline \multirow{3}{*}{$\begin{array}{c}\text { A Corporate } \\
\text { Attribute }\end{array}$} & $\mathrm{a}_{1}$ Industrial Trait & $\begin{array}{l}\text { The external environmental factors that } \\
\text { family businesses face in order to survive, } \\
\text { such as economic, social, legal, technical } \\
\text { and environmental protection. }\end{array}$ & \multirow{3}{*}[12,22-27]{} \\
\hline & $\mathrm{a}_{2}$ Corporate Style & $\begin{array}{l}\text { In order to manage the enterprise, the } \\
\text { ownership structure is designed by the } \\
\text { family business during the process of } \\
\text { development. The governance mode for } \\
\text { this ownership structure is shown by how } \\
\text { ownership, management and control } \\
\text { are separated. }\end{array}$ & \\
\hline & $\mathrm{a}_{3}$ Business Scale & $\begin{array}{l}\text { According to different classification } \\
\text { standards (such as the number of } \\
\text { employees, production capacity, fixed } \\
\text { asset value, etc.), family businesses can be } \\
\text { divided into large enterprises, medium } \\
\text { enterprises and small enterprises. }\end{array}$ & \\
\hline
\end{tabular}


Table 1. Cont.

\begin{tabular}{|c|c|c|c|}
\hline Dimension & Criteria & Description & References \\
\hline \multirow{2}{*}{$\begin{array}{l}\text { B Governance } \\
\text { Variables }\end{array}$} & $\mathrm{b}_{1}$ Equity Structure & $\begin{array}{l}\text { The proportion of different types of } \\
\text { shares and their interrelationships, such } \\
\text { as the degree of concentration or } \\
\text { dispersion of equity in the } \\
\text { shareholding structure. }\end{array}$ & \multirow{2}{*}[14,28-34]{} \\
\hline & $\begin{array}{l}\mathrm{b}_{2} \text { Governance } \\
\text { Culture }\end{array}$ & $\begin{array}{l}\text { The degree of capital socialization and } \\
\text { management socialization in family } \\
\text { businesses, such as the centralization of } \\
\text { family interests and the socialization of } \\
\text { family interests. }\end{array}$ & \\
\hline \multirow{3}{*}{$\begin{array}{l}\text { C Management } \\
\text { Concern }\end{array}$} & $c_{1}$ Leadership Style & $\begin{array}{l}\text { Leadership styles displayed in family } \\
\text { businesses can include totalitarian } \\
\text { authoritative leadership, decentralized } \\
\text { professional leadership or group } \\
\text { consensus collective leadership. }\end{array}$ & \multirow{3}{*}[20,35-43]{} \\
\hline & $\begin{array}{l}\mathrm{c}_{2} \text { Employment } \\
\text { Philosophy }\end{array}$ & $\begin{array}{l}\text { The mechanisms and practices for } \\
\text { managing human resources in family } \\
\text { businesses, such as relationship oriented, } \\
\text { technology oriented or } \\
\text { professional oriented. }\end{array}$ & \\
\hline & $\begin{array}{c}\mathrm{c}_{3} \text { Communication } \\
\text { Mode }\end{array}$ & $\begin{array}{l}\text { The arbitrariness or democratic nature of } \\
\text { family business decision-making; the } \\
\text { mode of horizontal or vertical } \\
\text { communication; the standard of } \\
\text { performance appraisal and job promotion }\end{array}$ & \\
\hline \multirow{3}{*}{$\begin{array}{l}\text { D Family } \\
\text { Capital }\end{array}$} & $\mathrm{d}_{1}$ Family Structure & $\begin{array}{l}\text { The tangible types of interpersonal } \\
\text { relationships within the family structure, } \\
\text { such as social relationships between } \\
\text { members of different hierarchical levels, } \\
\text { pedigree, primogeniture }\end{array}$ & \multirow{3}{*}[13,27,44-49]{} \\
\hline & $\mathrm{d}_{2}$ Family Tradition & $\begin{array}{l}\text { The tradition of the family is usually } \\
\text { reflected in the family beliefs or customs } \\
\text { that family members share and abide by, } \\
\text { such as the customs, conventions and } \\
\text { family rules or family constitutions. }\end{array}$ & \\
\hline & $\begin{array}{l}\mathrm{d}_{3} \text { Affection } \\
\text { relationship }\end{array}$ & $\begin{array}{l}\text { Intangible interpersonal relationships in } \\
\text { the family structure, such as family } \\
\text { affection or obedience, unity and cohesion }\end{array}$ & \\
\hline \multirow{2}{*}{$\begin{array}{c}\text { E Niche } \\
\text { Inheritance }\end{array}$} & $\begin{array}{l}\mathrm{d}_{1} \text { Succession } \\
\text { Planning }\end{array}$ & $\begin{array}{l}\text { The company develops and builds a } \\
\text { high-potential successor tracking and } \\
\text { developing mechanism that is closely } \\
\text { integrated with the company's overall } \\
\text { business strategy. }\end{array}$ & \multirow[t]{2}{*}[8,34,39,50,51]{} \\
\hline & $\begin{array}{c}\mathrm{d}_{2} \text { Requirement } \\
\text { profiles }\end{array}$ & $\begin{array}{l}\text { The requirements of the predecessors and } \\
\text { the expected skills of the successor, both } \\
\text { explicit and implicit requirements such as } \\
\text { soft and hard skills. }\end{array}$ & \\
\hline
\end{tabular}

\section{Methodology}

\subsection{Grounded Theory and a Decisive Factor Analysis Framework of Succession}

A good succession plan helps with the smooth implementation of family business succession over the generations. This study is based on feedback from business owners participating in Taiwan family 
business training courses. The aim of this study is to construct an analytical framework containing the key decision-making factors for family business succession. To begin the process of analyzing the data related to family business succession, we first conduct a lengthy review of the literature. We adopt the qualitative research method of semi-structured interviews. The inheritance factors are organized into five pre-planned groups including corporate attributes, governance variables, management concerns, family capital and niche inheritance. These five pre-planned dimensions are extracted from 12 potential topics suggested by experts or obtained based on empirical materials collected from case studies, then used to explore considerations for intergenerational transitions involving family succession. The findings are refined into five facets to be used as research lenses and variables of interest.

As noted by Corbin and Strauss [52] in their seminal work, grounded theory is a systematic methodology used in the social sciences, where theory is constructed through methodical gathering and analysis of data. In other words, there is no pre-conceived theory in the researcher's mind, rather the theory gradually emerges from the data. This qualitative research method is characterized by viewing the world from the perspective of the actor, rather than using the values or the world view of the researcher to construct the framework.

The content of the interview outline is roughly divided into two parts: the first part is used to collect background information from the interviewer, and the second part is designed to further explore the factors for consideration in family business inheritance. The interview questions are listed in Table 2 below.

Table 2. The content of the interview on business firm succession.

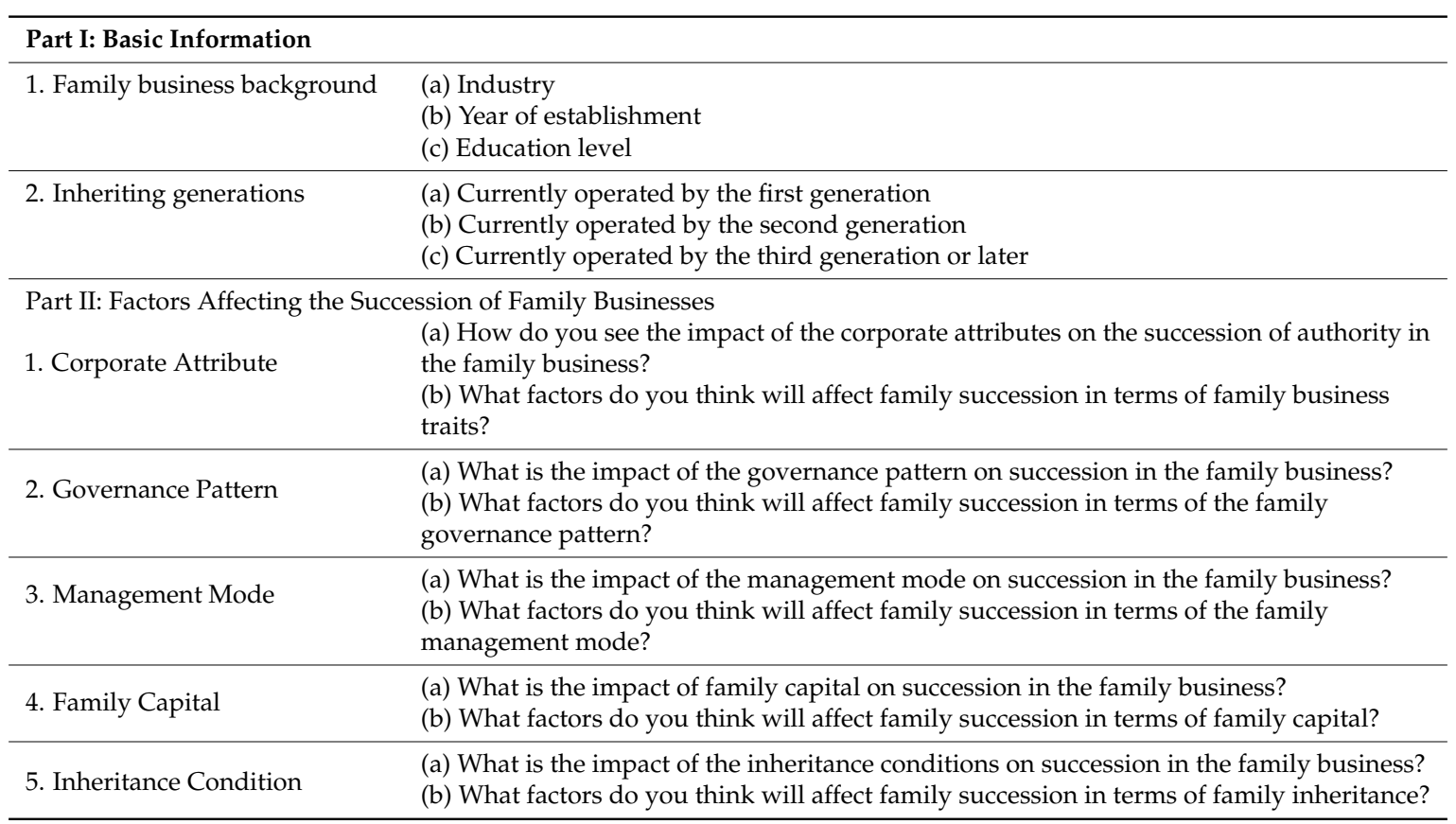

To compensate for the limitations in the literature, respondents are free to express their thoughts about the key factors related to inheritance. Therefore, during the interview process, the researchers asked the respondents to express themselves freely within the framework of the problem. The steps followed for the interview procedure are as follows:

Step 1: Translate the information obtained from the interview into a draft: In order to ensure that the data are as authentic as possible, the researcher tried to use a word-by-word translation method, but skipped unnecessary repetitions and irrelevant content. After the translation process was completed, in order to protect the privacy of the interviewee and prevent others from guessing their identity, some parts or information that might reveal the identity of the interviewee are represented by a letter code, and parts that are not related to the study are deleted. 
Step 2: Encoding the text draft: Because of the length of the verbatim draft, the content of the different questions is classified first, and then encoded line by line. This coding method can structure the verbatim manuscript in a way that is convenient for both researchers and readers to quickly find the corresponding source of the article citation.

Step 3: Identifying the descriptions of the key factors affecting succession: Researchers repeatedly read the verbatim scripts to find those statements that described key factors affecting family business succession, which were then coded, condensed into short sentences, and recorded in a verbatim paragraph.

Step 4: The above information was combined with information from the literature review and the essence of the key factors of succession integrated and summarized to arrive at five aspects of belonging.

Step 5: The factors that the researcher considers to be relevant to succession are derived based on the results of the previous steps. Finally, to ensure that the factors extracted by the grounded theory methodology are valid, they are modified based on the knowledge and experience of experts who were asked to make recommendations for each standard to ensure the validity of the research framework and to confirm the final results.

Finally, the resultant content of the interview responses was coded by the application of grounded theory. The coded factors that affected family inheritance planning were collected and listed, with a total of 18 criteria used as the basis of the pre-test questionnaire.

As recommended by Saaty [53], the number of factors within a single dimension was limited to ensure the validity and consistency of the pairwise comparisons, and a questionnaire survey of experts was used to obtain the relative importance of the criteria. The 14 domain experts were lecturers in family business inheritance training classes who had a solid theoretical and/or practical insights of the transferring and succession of family enterprises. Regarding the background of these 14 experts, there were 3 high school graduates, 7 university graduates and 4 had Ph.Ds. They were between 28 and 55 years old.

In addition, criteria were defined as important if the triangular fuzzy numbers had a mean value of eight or above. The pre-test questionnaire was scored on a scale of zero to 10, with a higher score representing greater importance. The pre-test results indicated that 13 criteria of the 18 should be adopted. From the afore-mentioned multidimensional evaluation groups that determine the inheritance management of family businesses, we identified the key succession indicators in each of the major groups. This phase ended when the research framework was consistently validated. The revised framework and meaningful terms and descriptions are shown in Figure 1 and Table 1 below.

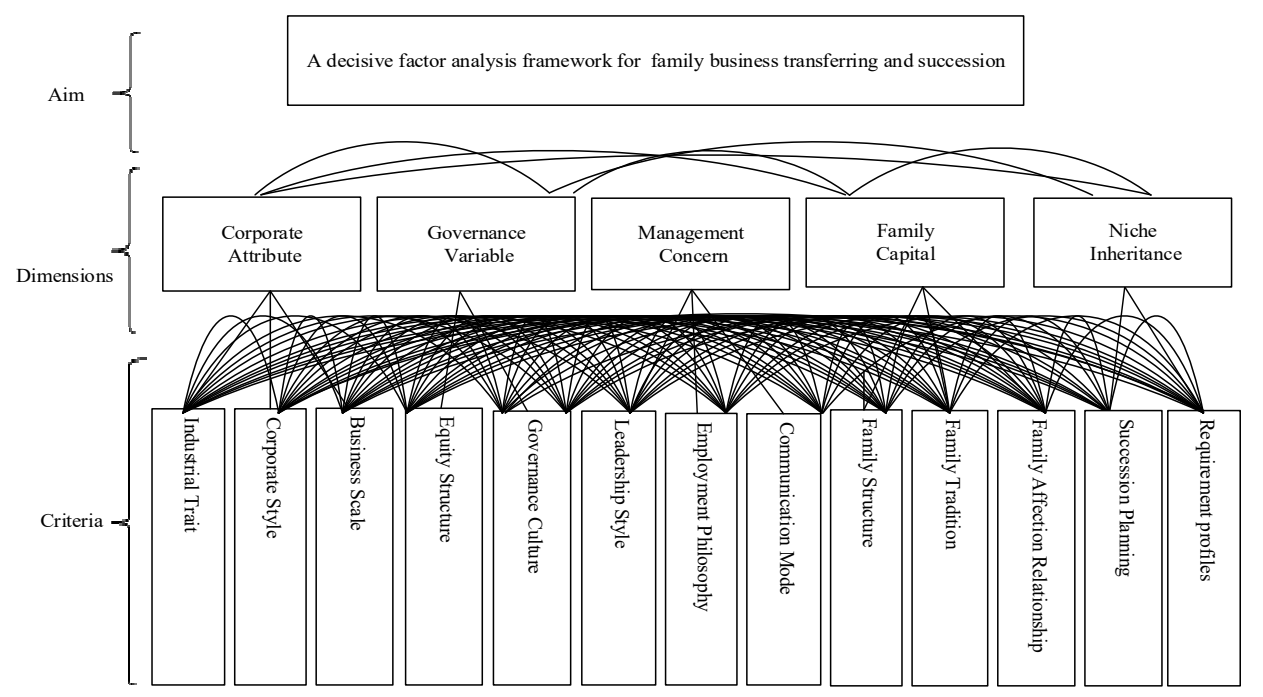

Figure 1. A decision factor analysis framework for family business transferring and succession. 


\subsection{Evaluation Methods and Operational Procedure}

In the real world, the factors affecting family business transmission and inheritance show multi-dimensional and multi-criteria decision-making characteristics. The facets and criteria for the key considerations are not independent of each other, but have mutually influential relationships, and sometimes, there is even a feedback and dynamic cause-effect relationship between them. Therefore, after establishing the research framework, in order to further understand the priorities and interactive relationship between the considerations affecting family business inheritance, this study first uses DEMATEL to build an influential network relationship diagram (INRM). The influential network diagrams can not only help researchers avoid unrealistic individual and independent assumptions, but also systematically clarify the interdependence and feedback relationships of the criteria and dimensions in real-world problems [54]. After clarifying the relationship between multiple criteria, we then use the analytic network process (ANP) to compare the criteria and calculate the weights of the considerations in the framework of family business succession. Finally, in order to more accurately grasp the decision-making direction for family inheritance, the VIKOR (VlseKriterijumska Optimizacija I Kompromisno Resenje) method is integrated with the multi-criteria decision-making method to carry out analysis of the positive-ideal and the negative-ideal solution.

Tsai et al. [55] pointed out in his recent study that the integration of the above three research methods has the following three advantages. First, the use of the DEMATEL method can illustrate the interrelationship among criteria, thereby removing the constraints imposed by the assumption in conventional analytical techniques that the evaluation criteria are independent of one another. Second, prioritization and selection can be executed despite any conflicts among the attributes. In addition, the VIKOR method uses the ideal standard, rather than a relative standard, as the benchmark to avoid choosing the best option from bad batches [56]. Therefore, the aspired to improvement strategies can be proposed systemically at the source of the impacts.

Based on the above three analytical techniques, accordingly, this study divides the detailed operational procedure of the decision-making model into three phases and demonstrates the calculations involved in each phase with the aid of Figure 2: 
What are the relationships between these factors of decision-making considerations for family business transferring and Succession

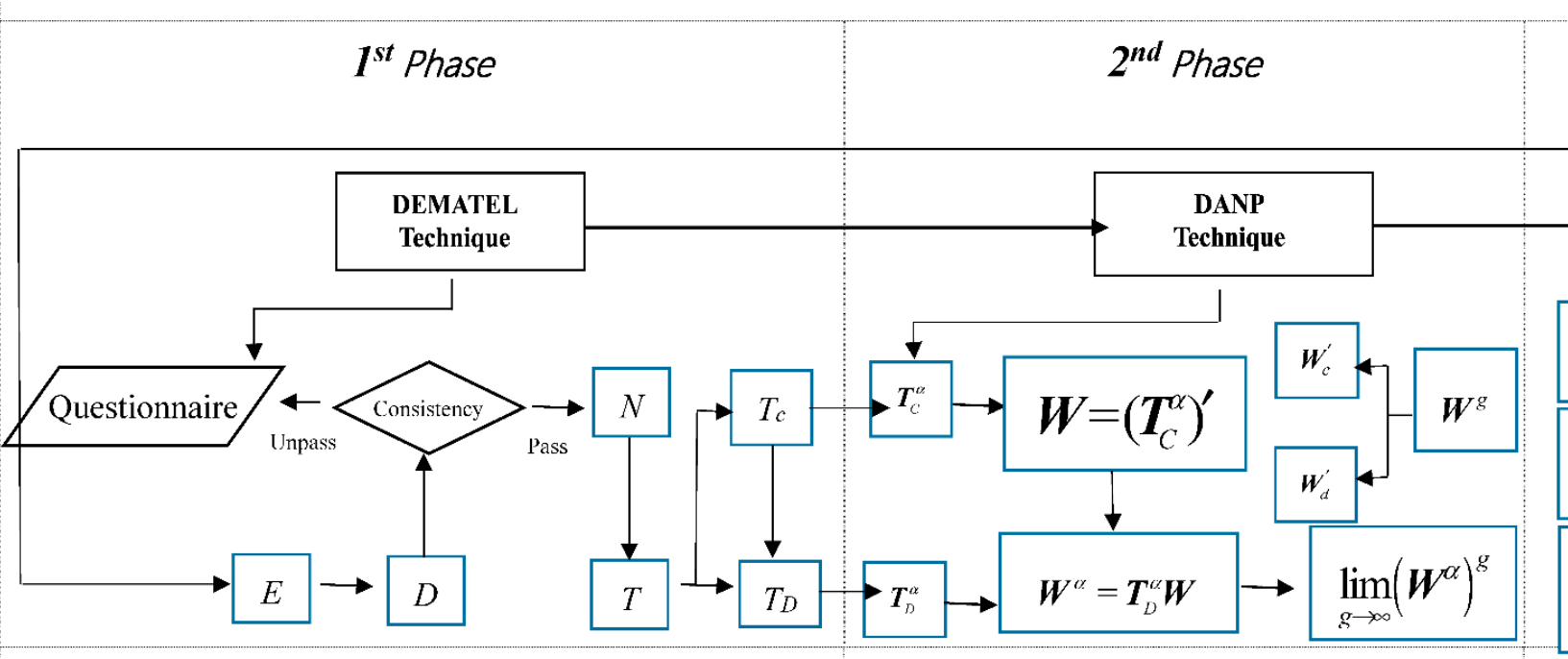

Obtain Influential Network Relation Map (INRM):
How to achieve and assess effective family business succession priorities
Develop and formulate appropriate family business succession development strategies

\section{$I^{\text {st }}$ Phase:}

$\mathrm{E}$ denotes the direct influence relation matrix; $\mathrm{D}$ denotes the average direct influence relation matrix; $\mathrm{N}$ denotes the normalized average direct influence relation matrix; $\mathrm{T}$ denotes the total influence relation matrix; Tc denotes the total influence relation matrix of criteria; $T_{D}$ denotes the total influence relation matrix of dimensions.

\section{$2^{\text {nd }}$ Phase:}

DANP(DEMATEL-Based ANP); $\boldsymbol{T}^{\alpha}$ denotes the normalizing total influence relation matrix of criteria; $\boldsymbol{T}^{\alpha}$ denotes the normalizing total influence relation matrix of dimensions; $\boldsymbol{W}^{a}$ denotes the unweighted supermatrix; $\boldsymbol{W}$ denotes the weighted supermatrix; $\boldsymbol{W}^{g}$ denotes the global weight; $\boldsymbol{W}_{c}^{\prime}$ denotes the local weight of criteria; $\boldsymbol{W}_{d}^{\prime}$ denotes the local weight of dimensions.

$3^{\text {th }}$ Phase:

$S_{k}$ denotes the satisfaction level of each criteria; $R_{k}$ denotes the gap of each criteria; $Q_{k}$ denotes the mean group utility for the gap.

Figure 2. Flowchart for the operational procedure. DEMATEL, decision-making trial and evaluation laboratory method; VIKOR, VlseKriterijumska Optimizacija I Kompromisno Resenje. 


\section{Empirical Analysis of the Key Influential Factors in Family Business Succession}

In the empirical analysis phase, the official questionnaire was formulated as in Table 1 and shown in Supplementary Material. The respondents were either business owners or members attending the Taiwan Family Business Inheritance Training Course. A total of 118 survey responses were retrieved; among the respondents, $50.8 \%$ were first-generation owners and $44.1 \%$ were second-generation owners. Only $5.1 \%$ remain for the third generation owners. The remaining $6 \%$ were third generation owners. The respondents ranged in age from 23 to 73 years old. The level of education ranged from high school graduates to holders of doctoral degrees in a variety of disciplinary areas. The industrial structure included the primary, secondary and tertiary sector. The results for the backgrounds of the survey participants are summarized in Table 3.

Table 3. Detailed information about interviewees.

\begin{tabular}{cccc}
\hline Category & Content & N & Percentage \\
\hline \multirow{3}{*}{ Generation } & First-generation owners & 60 & $50.8 \%$ \\
& Second-generation owners & 52 & $44.1 \%$ \\
& Third generation of owners & 6 & $5.1 \%$ \\
\hline \multirow{2}{*}{ Sex } & Male & 86 & $72.9 \%$ \\
& Female & 32 & $27.1 \%$ \\
\hline \multirow{5}{*}{ Education level } & Doctorate & 4 & $3.3 \%$ \\
& Master's & 42 & $35.6 \%$ \\
& Undergraduate & 63 & $53.4 \%$ \\
& High School and Below & 9 & $7.7 \%$ \\
\hline \multirow{2}{*}{ Industry } & Primary industrial sectors & 8 & $6.7 \%$ \\
& Secondary industrial sectors & 62 & $52.5 \%$ \\
& Tertiary industrial sectors & 48 & $40.8 \%$ \\
\hline
\end{tabular}

\subsection{Results of the DEMATEL}

This study used pairwise comparison to investigate the dimension and criteria of impact for each participant. Using the methodology described above and based on the data collected from the respondents, we derive a $13 \times 13$ average initial direct-influence matrix $\mathrm{T}$, including 13 criteria. The total influence-relation matrices shown in Tables 4 and 5 can be obtained on the basis of the normalization impact matrix described above.

Table 4. Total influence-relation matrix of criteria.

\begin{tabular}{cccccccccccccc}
\hline Criteria & $\mathbf{a}_{\mathbf{1}}$ & $\mathbf{a}_{\mathbf{2}}$ & $\mathbf{a}_{\mathbf{3}}$ & $\mathbf{b}_{\mathbf{1}}$ & $\mathbf{b}_{\mathbf{2}}$ & $\mathbf{c}_{\mathbf{1}}$ & $\mathbf{c}_{\mathbf{2}}$ & $\mathbf{c}_{\mathbf{3}}$ & $\mathbf{d}_{\mathbf{1}}$ & $\mathbf{d}_{\mathbf{2}}$ & $\mathbf{d}_{\mathbf{3}}$ & $\mathbf{e}_{\mathbf{1}}$ & $\mathbf{e}_{\mathbf{2}}$ \\
\hline $\mathrm{a}_{1}$ & 0.014 & 0.152 & 0.151 & 0.145 & 0.157 & 0.151 & 0.125 & 0.114 & 0.030 & 0.126 & 0.112 & 0.154 & 0.149 \\
\hline $\mathrm{a}_{2}$ & 0.019 & 0.057 & 0.148 & 0.132 & 0.146 & 0.158 & 0.147 & 0.137 & 0.047 & 0.114 & 0.101 & 0.136 & 0.138 \\
\hline $\mathrm{a}_{3}$ & 0.015 & 0.089 & 0.052 & 0.088 & 0.105 & 0.137 & 0.125 & 0.119 & 0.044 & 0.098 & 0.076 & 0.112 & 0.146 \\
\hline $\mathrm{b}_{1}$ & 0.018 & 0.092 & 0.118 & 0.053 & 0.136 & 0.175 & 0.172 & 0.148 & 0.030 & 0.093 & 0.082 & 0.126 & 0.122 \\
\hline $\mathrm{b}_{2}$ & 0.020 & 0.077 & 0.102 & 0.101 & 0.063 & 0.151 & 0.163 & 0.134 & 0.022 & 0.080 & 0.081 & 0.111 & 0.108 \\
\hline $\mathrm{c}_{1}$ & 0.030 & 0.059 & 0.069 & 0.070 & 0.110 & 0.073 & 0.160 & 0.171 & 0.026 & 0.099 & 0.090 & 0.126 & 0.103 \\
\hline $\mathrm{c}_{2}$ & 0.034 & 0.063 & 0.055 & 0.045 & 0.090 & 0.116 & 0.059 & 0.122 & 0.022 & 0.080 & 0.074 & 0.104 & 0.088 \\
\hline $\mathrm{c}_{3}$ & 0.017 & 0.033 & 0.050 & 0.054 & 0.072 & 0.079 & 0.077 & 0.044 & 0.018 & 0.058 & 0.059 & 0.071 & 0.093 \\
\hline $\mathrm{d}_{1}$ & 0.013 & 0.059 & 0.065 & 0.078 & 0.088 & 0.093 & 0.106 & 0.110 & 0.014 & 0.068 & 0.060 & 0.111 & 0.108 \\
\hline $\mathrm{d}_{2}$ & 0.029 & 0.165 & 0.162 & 0.148 & 0.212 & 0.226 & 0.217 & 0.217 & 0.094 & 0.092 & 0.182 & 0.223 & 0.228 \\
\hline $\mathrm{d}_{3}$ & 0.022 & 0.145 & 0.137 & 0.120 & 0.155 & 0.182 & 0.177 & 0.176 & 0.057 & 0.129 & 0.066 & 0.160 & 0.184 \\
\hline $\mathrm{e}_{1}$ & 0.020 & 0.106 & 0.124 & 0.125 & 0.140 & 0.166 & 0.161 & 0.160 & 0.025 & 0.117 & 0.058 & 0.079 & 0.157 \\
\hline $\mathrm{e}_{2}$ & 0.010 & 0.061 & 0.066 & 0.057 & 0.062 & 0.073 & 0.081 & 0.072 & 0.025 & 0.061 & 0.072 & 0.101 & 0.047 \\
\hline & & & & & & & & & & & & &
\end{tabular}


Table 5. The sum of effects on dimensions.

\begin{tabular}{cccccc}
\hline Dimensions & A & B & C & D & E \\
\hline Corporate Attributes (A) & 0.462 & 0.777 & 0.865 & 0.690 & 0.621 \\
Governance Variables (B) & 0.373 & 0.332 & 0.667 & 0.370 & 0.375 \\
Management Concerns (C) & 0.273 & 0.267 & 0.241 & 0.216 & 0.205 \\
Family Capital (D) & 0.721 & 0.881 & 0.990 & 0.531 & 0.760 \\
Niche Inheritance (E) & 0.547 & 0.658 & 0.786 & 0.605 & 0.405 \\
\hline
\end{tabular}

As shown in Table 6, the sum of the influence of each dimension and criterion can be derived by applying Equations of DEMATEL. The INRM in Figure 3 illustrates the influential network-relationship between the five dimensions and their subsystems for the decisive factor analysis framework for family business transferring and succession.

According to the value of influence given $d_{i}-r_{i}$, management concerns (A) is influenced by governance variables (B), niche inheritance (E), corporate attributes (C) and family capital (D), because the $d_{i}-r_{i}$ value of management concerns (C) is negative and a minimum $(-2.346)$. The criteria with negative values of $d_{i}-r_{i}$ are greatly influenced by the other criteria. Conversely, a significantly positive value of $d_{i}-r_{i}$ represents that this criterion affects other criteria much more than those other criteria affect it, which means it should be a priority for improvement. Accordingly, management concerns (C) and governance variables (B) are influenced by niche inheritance $(E)$, whereas niche inheritance $(E)$ is influenced by family capital (D) and corporate attributes (A). Meanwhile, family capital (D) with a maximum value of $d_{i}-r_{i}(1.471)$ has the most influence on the other dimensions.

Due to different family backgrounds, resources and social networks, family businesses have formed different family traditions, which accumulate into unique family capital. Family capital is not only related to the development of the company, but also a key consideration during succession. Family capital will naturally conform to the development of the corporate environment and will lead to the development of differences in corporate forms and governance cultures during the life cycle of the family business. In order to ensure sustainable development of the family enterprise, it is also necessary to examine the place of family development and the enterprise environment, as well as adjustment of the modes of governance and management through the arrangement of the succession plan.

Through a close examination of Table 6, we can recognize how the dimensions of family capital (D), corporate variables (A), niche inheritance (E), governance patterns (B) and management concerns (C) interact and influence each other. To facilitate the success of the inheritance and help companies continue to operate sustainably, improvement and adjustment of the dimensions niche inheritance (E), corporate attributes (A) and family capital (D) should be emphasized. The priority of influence of the five dimensions is thus family capital (D), corporate variables (A), niche inheritance (E), governance patterns (B) and management concerns (C).

Table 6. The sum of influences and ranking of each dimension and criterion.

\begin{tabular}{cccccc}
\hline Dimensions and Criteria (i) & Row Sum $\left(\mathbf{d}_{\mathbf{i}}\right)$ & Column Sum $\left(\mathbf{r}_{\mathbf{i}}\right)$ & $\boldsymbol{d}_{\boldsymbol{i}}+\boldsymbol{r}_{\boldsymbol{i}}$ & $\boldsymbol{d}_{\boldsymbol{i}}-\boldsymbol{r}_{\boldsymbol{i}}$ & Ranking \\
\hline Corporate Attributes (A) & 3.414 & 2.376 & 5.790 & 1.038 & \\
a $_{1}$ Industrial Traits & 1.580 & 0.260 & 1.840 & 1.320 & 1 \\
$\mathrm{a}_{2}$ Corporate Style & 1.480 & 1.158 & 2.638 & 0.321 & 2 \\
a $_{3}$ Business Scale & 1.207 & 1.298 & 2.504 & -0.091 & 3 \\
Governance Variables (B) & 2.117 & 2.915 & 5.032 & -0.798 & \\
b $_{1}$ Equity Structure & 1.366 & 1.216 & 2.582 & 0.150 & 1 \\
$\mathrm{~b}_{2}$ Governance Culture & 1.213 & 1.537 & 2.750 & -0.324 & 2 \\
Management Concerns (C) & 1.202 & 3.548 & 4.751 & -2.346 & \\
c Leadership Style & 1.186 & 1.779 & 2.964 & -0.593 & 1 \\
$\mathrm{c}_{2}$ Employment Philosophy & 0.950 & 1.770 & 2.720 & -0.819 & 2 \\
\hline
\end{tabular}


Table 6. Cont.

\begin{tabular}{cccccc}
\hline Dimensions and Criteria (i) & Row Sum $\left(\mathbf{d}_{\mathbf{i}}\right)$ & Column Sum $\left(\mathbf{r}_{\mathbf{i}}\right)$ & $\boldsymbol{d}_{\boldsymbol{i}}+\boldsymbol{r}_{\boldsymbol{i}}$ & $\boldsymbol{d}_{\boldsymbol{i}}-\boldsymbol{r}_{\boldsymbol{i}}$ & Ranking \\
\hline $\mathrm{c}_{3}$ Communication Mode & 0.723 & 1.723 & 2.446 & -1.000 & 3 \\
Family Capital (D) & 3.883 & 2.413 & 6.296 & 1.471 & \\
$\mathrm{~d}_{1}$ Member Structure & 0.972 & 0.455 & 1.427 & 0.516 & 3 \\
$\mathrm{~d}_{2}$ Family Traditions & 2.195 & 1.216 & 3.411 & 0.979 & 1 \\
$\mathrm{~d}_{3}$ Family Affection Relationships & 1.710 & 1.112 & 2.822 & 0.597 & 2 \\
Niche Inheritance (E) & 3.000 & 2.366 & 5.367 & 0.634 & \\
e e $_{1}$ Successor Planning & 1.438 & 1.613 & 3.050 & -0.175 & 1 \\
$\mathrm{e}_{2}$ Requirement profiles & 0.787 & 1.670 & 2.457 & -0.882 & 2 \\
\hline
\end{tabular}

\subsection{Analysis of the Relationships between Dimensions and Criteria}

As shown in Table 6 and Figure 3, the analysis of each criterion shows that in the corporate attribute (A) dimension, industrial traits $\left(\mathrm{a}_{1}\right)$ is the most important criterion $\left(d_{i}-r_{i}=1.32\right)$, and business scale $\left(a_{3}\right)$ is the least influential $\left(d_{i}-r_{i}=-0.091\right)$. First of all, in terms of corporate attributes, the type of industry, company size, social network and industrial environment in which the family business operates all have different requirements for the qualifications of the successor. The attributes of the industry will also influence the subsequent planning of corporate equity and governance structure, thus affecting intergenerational inheritance and succession planning. The type of corporate style not only also affects the model of family intergenerational succession, but also the required abilities of successors, and this can be different at different stages of family business development. In addition, the scale of the firm is often seen as an important factor influencing the development and implementation of the succession plan. The larger the family enterprise, the more likely that professional managers will be introduced to assist with the business or be replaced by suitable successors. Enterprises also have to adapt to changes in the industrial environment. Thus, the style of the enterprise will change in response to market changes, the scale of the enterprise will continue to expand, and the challenges of employing people will increase, so the needs of successors will be different.

In the governance variables (B) dimension, equity structure $\left(b_{1}\right)$ is the most important criterion $\left(d_{i}-r_{i}=0.15\right)$, whereas governance culture $\left(\mathrm{b}_{2}\right)$ is the least influential criterion $\left(d_{i}-r_{i}=-0.324\right)$. It is generally believed that corporate governance is clear, equity structure is balanced and the introduction of external independent directors facilitates the initiation of the inheritance process and the implementation of the succession plan. Family businesses often use industrial advantages to design complex equity and sophisticated family equity structures, reducing the need for successor management skills and reducing the impact of uncertainty in the external environment on the succession process [57]. In addition, corporate governance culture is also an important factor affecting family heritage.

In the dimension of management concerns $(C)$, leadership style $\left(c_{1}\right)$ is the most important criterion $\left(d_{i}-r_{i}=-0.267\right)$, whereas communication mode $\left(\mathrm{c}_{3}\right)$ is the least influential criterion $\left(d_{i}-r_{i}=-1.000\right)$. In family businesses, ownership and management rights are generally in the hands of the founders of the company. Leaders often play a key role in the business team or within the family. Therefore, the leader's leadership style, human resource appointment mode and communication mode will affect the development and planning of the family business succession. If the leadership style of the family business is single-paternalistic with a relationship orientation, rather than being performance-based, or focused on group communication, technology or work specialization, then it is easier for the family business to recruit from within the family and rule out non-kin. Furthermore, leadership is more likely to be passed on to family members. Modern enterprises should establish a sound mechanism for the development of human resources, and this mechanism is an important guarantee of success in the succession model.

In the dimension of family capital (D), family traditions $\left(\mathrm{d}_{1}\right)$ is the most important criterion $\left(d_{i}-r_{i}=0.979\right)$, whereas member structure $\left(d_{3}\right)$ is the least influential criterion $\left(d_{i}-r_{i}=0.516\right)$. 
The importance of the family capital variables in the process of family business inheritance is unquestionable, because family membership is at the core of the family business and the primary consideration for succession. Barach et al. [22], Lansberg and Astrachan [14] pointed out that the family membership structure, family traditions, family relationships and family cohesion have important impacts on the implementation of succession plans. Therefore, Barach [29] argued that the family capital of family stakeholders is one of the most important factors affecting inheritance and development in family businesses. In addition, family capital is particularly meaningful for family succession. Positive family capital can increase family wealth, while negative family capital (such as struggles, accusations and even lawsuits between family members) will destroy the family's wealth. Unity and trust within the family will allow the family assets to grow generation by generation, and such capital can be reflected in family capital by family discipline, family rules and family traditions. Lansberg and Astrachan [14] argued that family harmony, prestige and cohesion have a significant impact on the implementation of succession programs.

In the dimension of niche inheritance $(E)$, successor planning $\left(e_{1}\right)$ is the most important criterion $\left(d_{i}-r_{i}=-0.175\right)$, whereas willingness and commitment $\left(\mathrm{e}_{2}\right)$ is the least influential criterion $\left(d_{i}-r_{i}=-0.882\right)$. Whether the successor's qualifications are sufficient to take on the operational burden of family business is also an important consideration. Succession is definitely not an easy task. It is not easy for the successor to take over and continue to run the business. The key to a company's long-term stability is that its core values can be confirmed by its successors. The experiences, conditions (hard skills, soft skills, personality traits, predecessor-successor relationship), encouragement of continued sustainable development of the enterprise, patterns of innovation and even the leadership and vision of the successor are also important factors that cannot be ignored [58]. For example, Stavrou [8] showed that the key players, that is the willingness and commitment of successors in the process of inheritance should not only receive sufficient attention, but should also be included in the analytical framework of the succession process. Moreover, a company must be able to maintain long-term stability, and business owners generally believe that succession planning is important. The corporate succession plan requires systematic and effective acquisition and organization of human resources. Therefore, the development of a continuous and fair corporate succession plan is of vital importance to the company's succession and sustainable development. 

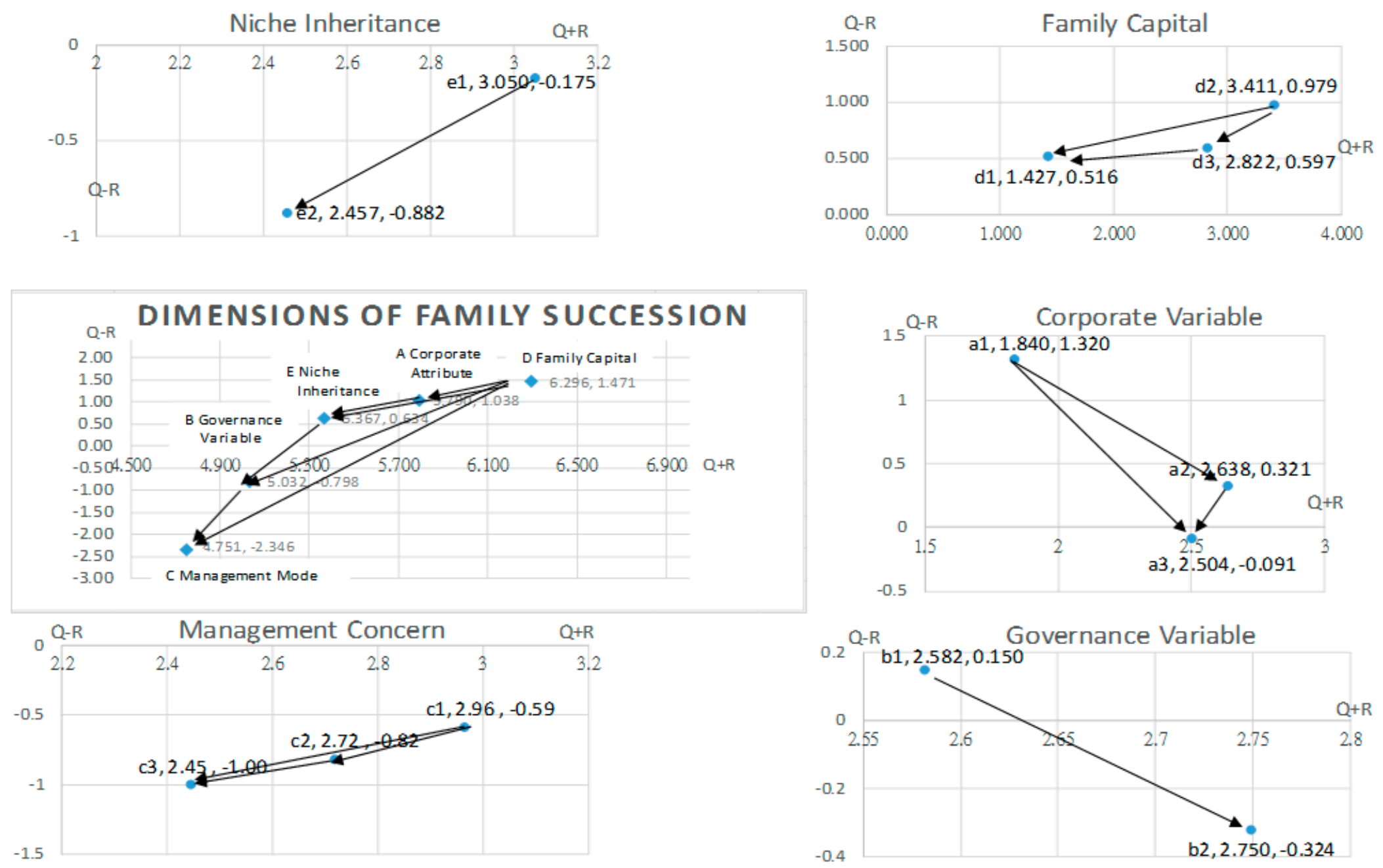

Figure 3. Maps of the influential network relations of each dimension and criterion. 


\subsection{Using DANP for Computing the Weights of the Criteria}

In the next section, the most accurate influential weights can be obtained after confirming the influential relationships among the criteria. Using a combination of the DEMATEL and ANP methods, we obtain the DANP (DEMATEL-Based ANP) influential weights for each criterion as shown in Table 7. The DANP approach allows us to derive the local weights of the assessment factors at their respective hierarchical levels and the global weights, which helps us comprehend the absolute weights of individual criteria across all five dimensions. The DEMATEL total influence-relation matrix is employed to build the weighted supermatrix by using Equations of DANP. The weighted supermatrix for each criterion can be acquired by applying Equations of DANP. Thus, the limit supermatrix is employed to acquire the global weights of the elements, which are applied to the modified VIKOR approach to evaluate the sustainability performance of the case companies.

Table 7. Influential weights of DANP for each criterion obtained by $\lim _{n \rightarrow \infty}\left(W^{\alpha}\right)^{n}$.

\begin{tabular}{cccc}
\hline \multirow{2}{*}{ Dimension } & Criteria & Weight & Rank \\
\hline \multirow{3}{*}{ A Corporate Attributes } & a1 Industrial Trait & 0.172694 & 2 \\
\cline { 2 - 4 } & a2 Corporate Style & 0.089596 & 5 \\
\cline { 2 - 4 } & a3 Business Scale & 0.073425 & 6 \\
\hline \multirow{2}{*}{ B Governance Pattern } & b1 Equity Structure & 0.042153 & 9 \\
\cline { 2 - 4 } & b2 Governance Culture & 0.032147 & 10 \\
\hline \multirow{3}{*}{ C Management Concerns } & c1 Leadership Style & 0.024949 & 11 \\
\cline { 2 - 4 } & c2 Employment Philosophy & 0.019127 & 12 \\
\cline { 2 - 4 } & c3 Communication Concerns & 0.015658 & 13 \\
\cline { 2 - 4 } D Family Capital & d1 Member Structure & 0.090343 & 4 \\
\cline { 2 - 4 } & d2 Family Tradition & 0.186620 & 1 \\
\hline \multirow{2}{*}{ E Inheritance Condition } & d3 Family Affection Relationships & 0.136879 & 3 \\
\cline { 2 - 4 } & e1 Successor Planning & 0.069079 & 7 \\
\hline
\end{tabular}

\subsection{Sustainability Performance Evaluation Obtained Using VIKOR}

Next, the respondents were invited to assign linguistic values for thirteen criteria, to evaluate the decisive factor analysis framework. The criteria for the decisive factors are rated from one to 100 , with one being the lowest and 100 the highest. The higher the rating is, the higher the satisfaction level. Finally, the global weights obtained from DANP in VIKOR are used to obtain the values of $S_{j}$ and $Q_{j}^{\text {mod }}$ by selecting $v=0.5$ as in Equations of VIKOR, and the results are shown in Table 8.

The compromise ranking method not only assists researchers to evaluate the overall performance gap across years, but also helps determine and prioritize strategies in different years. From Table 8 , one can see the $S_{j}$ values of three years ago, the current $S_{j}$ values, the $R_{j}^{\text {mod }}$ values of three years ago and the current $R_{j}^{\text {mod }}$. The values of "concordance" $\left(S_{j}\right)$ and "discordance" $\left(R_{j}^{\text {mod }}\right)$ represent the group utility and the individual regret measures, respectively, for alternative $a_{j}$. In addition, the $Q_{j}^{\text {mod }}$ values of three years ago are $\left(\mathrm{a}_{1}, \mathrm{a}_{2}, \mathrm{a}_{3}, \mathrm{~b}_{1}, \mathrm{~b}_{2}, \mathrm{c}_{1}, \mathrm{c}_{3}, \mathrm{c}_{4}, \mathrm{~d}_{1}, \mathrm{~d}_{2}, \mathrm{~d}_{3}, \mathrm{e}_{1}, \mathrm{e}_{2}\right)=(0.082,0,163,0.215,0.261,0.284$, $0.282,0.285,0.305,0.218,0.059,0.091,0.187,0.262$, respectively); the current $Q_{j}^{\text {mod }}$ values are $\left(\mathrm{a}_{1}, \mathrm{a}_{2}\right.$, $\left.a_{3}, b_{1}, b_{2}, c_{1}, c_{3}, c_{4}, d_{1}, d_{2}, d_{3}, e_{1}, e_{2}\right)=(0.419,0,386,0.196,0.413,0.420,0.432,0.663$, respectively). Accordingly, the empirical results for three years ago can be ranked as follows: $d_{2}>a_{1}>d_{3}>$ $\mathrm{a}_{2}>\mathrm{e}_{1}>\mathrm{a}_{3}>\mathrm{d}_{1}>\mathrm{e}_{2}>\mathrm{b}_{1}>\mathrm{c}_{1}>\mathrm{b}_{2}>\mathrm{c}_{2}>\mathrm{c}_{3}$, where $A>B$ means that $\mathrm{A}$ is preferred over B. The alternative closest to the ideal solution has the smallest value of $Q_{j}^{\text {mod }}$. The current empirical results can be ranked as follows: $d_{2}>d_{3}>e_{1}>a_{1}>a_{2}>e_{2}>a_{3}>d_{1}>b_{1}>c_{1}>b_{2}>c_{2}>c_{3}$. 
Meanwhile, a compromise solution could be accepted by the decision-makers because it provides the maximum "group utility" (measure $S_{j}$ represents "concordance") and a minimum of individual regret of the "opponents" (measure $\mathrm{R} R_{j}^{\bmod }$ represents "discordance") [59].

Table 8. Gap ratio values obtained by VIKOR.

\begin{tabular}{|c|c|c|c|c|c|c|c|c|c|c|}
\hline & \multirow{2}{*}{ Dimension } & & \multirow{2}{*}{ Criteria } & \multirow{2}{*}{$\begin{array}{c}\text { Global } \\
\text { Weight (by } \\
\text { DANP) }\end{array}$} & \multicolumn{3}{|c|}{ Three Years Ago } & \multicolumn{3}{|c|}{ Current Year } \\
\hline & & & & & $S_{j}$ & $R_{j}^{\text {mod }}$ & $Q_{j}^{m o d}$ & $S_{j}$ & $R_{j}^{\text {mod }}$ & $Q_{j}^{\text {mod }}$ \\
\hline \multirow{3}{*}{ A } & \multirow{3}{*}{$\begin{array}{l}\text { Corporate } \\
\text { Attributes }\end{array}$} & $\mathrm{a}_{1}$ & $\begin{array}{l}\text { Industrial } \\
\text { Environment }\end{array}$ & 0.173 & 0.024 & 0.082 & 0.140 & 0.043 & 0.147 & 0.250 \\
\hline & & $\mathrm{a}_{2}$ & Corporate Style & 0.090 & 0.027 & 0.163 & 0.300 & 0.027 & 0.163 & 0.300 \\
\hline & & $a_{3}$ & Business Scale & 0.073 & 0.029 & 0.215 & 0.400 & 0.029 & 0.215 & 0.400 \\
\hline \multirow[b]{2}{*}{ B } & \multirow{2}{*}{$\begin{array}{l}\text { Governance } \\
\text { Variables }\end{array}$} & $b_{1}$ & Equity Structure & 0.042 & 0.021 & 0.261 & 0.500 & 0.021 & 0.261 & 0.500 \\
\hline & & $b_{2}$ & $\begin{array}{l}\text { Governance } \\
\text { Culture }\end{array}$ & 0.032 & 0.018 & 0.284 & 0.550 & 0.018 & 0.284 & 0.550 \\
\hline \multirow{3}{*}{ C } & \multirow{3}{*}{$\begin{array}{l}\text { Management } \\
\text { Concerns }\end{array}$} & $\mathrm{c}_{1}$ & Leadership Style & 0.025 & 0.014 & 0.282 & 0.550 & 0.014 & 0.282 & 0.550 \\
\hline & & $\mathrm{c}_{2}$ & $\begin{array}{l}\text { Employment } \\
\text { Philosophy }\end{array}$ & 0.019 & 0.011 & 0.285 & 0.560 & 0.011 & 0.285 & 0.560 \\
\hline & & $c_{3}$ & $\begin{array}{l}\text { Communication } \\
\text { Mode }\end{array}$ & 0.016 & 0.009 & 0.305 & 0.600 & 0.009 & 0.305 & 0.600 \\
\hline \multirow{3}{*}{$\mathrm{D}$} & \multirow{3}{*}{$\begin{array}{l}\text { Family } \\
\text { Capital }\end{array}$} & $\mathrm{d}_{1}$ & Member Structure & 0.090 & 0.036 & 0.218 & 0.400 & 0.036 & 0.218 & 0.400 \\
\hline & & $\mathrm{d}_{2}$ & Family Tradition & 0.187 & 0.019 & 0.059 & 0.100 & 0.019 & 0.059 & 0.100 \\
\hline & & $d_{3}$ & $\begin{array}{c}\text { Family Affection } \\
\text { Relationships }\end{array}$ & 0.137 & 0.022 & 0.091 & 0.160 & 0.027 & 0.114 & 0.200 \\
\hline \multirow{2}{*}{ E } & \multirow{2}{*}{$\begin{array}{l}\text { Inheritance } \\
\text { Conditions }\end{array}$} & $\mathrm{e}_{1}$ & $\begin{array}{l}\text { Successor } \\
\text { Planning }\end{array}$ & 0.069 & 0.024 & 0.187 & 0.350 & 0.017 & 0.134 & 0.250 \\
\hline & & $\mathrm{e}_{2}$ & $\begin{array}{l}\text { Requirement } \\
\text { profiles }\end{array}$ & 0.047 & 0.024 & 0.262 & 0.500 & 0.019 & 0.209 & 0.400 \\
\hline
\end{tabular}

The empirical results show that family capital is still the most important factor of influence for inheritance, with the scores evaluated being closest to the ideal point. The performance variance rate for three years ago for family capital is 0.059 , indicating that there are still some gaps $(0.059)$ to the goal value (zero). The results of this study show that family businesses are not only deeply influenced by family traditions, but family members recognize family traditions. Note that the importance of continuing the family tradition is slightly greater than the impact of the family business variables. In the face of changes in the industrial environment, the will of the family will also influence the style of governance of the company. However, the results show that in the case of changes in the family business environment, the family capital and governance variables remain stable, and successor planning becomes an important consideration in order to cope with continued development. The results will also affect the requirement profiles. Therefore, the family business still hopes to continue its development through an appropriate inheritance plan.

\subsection{Discussion and Implications}

This paper proposes a hybrid model for the incorporation of critical dimensions and their associated criteria, drawn from decisive factor analysis for examination of family business authority transfer and succession and provides empirical evidence for the sequencing of the order of improvement for making inheritance decisions. The results show that there are five dimensions and 13 criteria that are the decisive factors affecting family business inheritance and that these are interdependent on and related to each another. Due to the diversity and complexity of succession decisions, the factors considered should not be limited to a single facet of family interests. The factors 
required for comprehensive consideration of succession must include the environment of the family business, overall future development, the existing structure and management concerns of the company and the basic conditions of the existing family succession such as the trust of the predecessor and the commitment of the heirs [20]. When the critical foundation of the considerations is unstable, the factors are not complete, or there is no comprehensive succession layout, the family's generational succession will be challenging, perhaps even doomed to failure.

From the dimension standpoint, the assessment strategy shows that family capital (D) is the most important and influential dimension affecting inheritance strategy; see Table 9. Prioritizing assessment dimensions from highest to lowest, we obtain the following: family capital (D) $\rightarrow$ corporate attributes (B) $\rightarrow$ niche inheritance (E) $\rightarrow$ governance variables (B) $\rightarrow$ management concerns (C).

Table 9. Priorities for improvement.

\begin{tabular}{|c|c|}
\hline Method & Priority for Improvement \\
\hline $\begin{array}{l}\text { Relational influence of dimensions' network } \\
\text { (per DEMATEL) }\end{array}$ & $\mathrm{D} \rightarrow \mathrm{A} \rightarrow \mathrm{E} \rightarrow \mathrm{B} \rightarrow \mathrm{C}$ \\
\hline \multirow{5}{*}{$\begin{array}{l}\text { Inter-dimensional influence of individual criteria } \\
\text { (per DEMATEL) }\end{array}$} & $\begin{array}{c}\mathrm{A}: \rightarrow\left(\mathrm{a}_{1}\right) \rightarrow\left(\mathrm{a}_{2}\right) \rightarrow\left(\mathrm{a}_{3}\right) \\
\quad\left(\mathrm{a}_{2}\right) \rightarrow\left(\mathrm{a}_{3}\right)\end{array}$ \\
\hline & B: $\left(b_{1}\right) \rightarrow\left(b_{2}\right)$ \\
\hline & $\begin{aligned} \mathrm{C}: \rightarrow & \left(\mathrm{c}_{1}\right) \rightarrow\left(\mathrm{c}_{2}\right) \rightarrow\left(\mathrm{c}_{3}\right) \\
& \left(\mathrm{c}_{2}\right) \rightarrow\left(\mathrm{c}_{3}\right)\end{aligned}$ \\
\hline & $\begin{array}{l}\mathrm{D}: \rightarrow\left(\mathrm{d}_{2}\right) \rightarrow\left(\mathrm{d}_{3}\right) \rightarrow\left(\mathrm{d}_{1}\right) \\
\quad\left(\mathrm{d}_{3}\right) \rightarrow\left(\mathrm{d}_{1}\right)\end{array}$ \\
\hline & $\mathrm{E}: \rightarrow\left(\mathrm{e}_{1}\right) \rightarrow\left(\mathrm{e}_{2}\right)$ \\
\hline
\end{tabular}

The five major facets and 13 criteria of family succession are integrated into an analytical framework. The results show that the factors for consideration of succession are not only diverse, but also require logical decision-making that is also relatively dynamic with consideration of mutual influence. When one of the key factors, such as the corporate environment or governance structure, changes, the priorities of other decision-making factors will change accordingly. From the criteria standpoint, the assessment strategy of inheritance showed family capital (D) to be the most important and influential dimension. Sorting the top five criteria from highest to lowest, we obtain the following: family tradition $\left(d_{2}\right) \rightarrow$ family affection relationships $\left(d_{3}\right) \rightarrow$ successor planning $\left(e_{1}\right) \rightarrow$ industrial traits $\left(\mathrm{a}_{1}\right) \rightarrow$ corporate style $\left(\mathrm{a}_{2}\right)$.

Based on field expert interviews and questionnaire responses, the results of this study provide a sequence of dimensions and criteria that will enable family businesses to more effectively analyze key inheritance factors and further promote the success of the family business through heritance. The results also show that family owners still perceive there to be room for improvement in the current status of family tradition $\left(\mathrm{d}_{2}\right)$, family affection relationships $\left(\mathrm{d}_{3}\right)$ and successor planning $\left(e_{1}\right)$ with values of $5.90 \%, 11.4 \%$ and $13.4 \%$, respectively. The research results show that in order to meet the needs of an optimal inheritance plan, business owners still believe that the current status of family capital and niche heritance still has room for improvement of $35.07 \%$ and $34 \%$, respectively. This improvement strategy would allow family businesses to achieve optimal results in terms of organizational reengineering, family business vision mapping and heritage succession as organizations face environmental changes. More importantly, the analytical framework and decision analysis method constructed in this paper can contribute to the theory of family business sustainable management, the continuation of the family business heritage and the development strategy. The research results can also be adapted to the decision-making environment of the family business and the strategic goals of inheritance and succession. 


\section{Conclusions and Limitations}

Family businesses are an important part of the world economy, and the successful realization of intergenerational inheritance is the key to ensuring the sustainable development of a family business [6,24]. It is estimated that only $20 \%$ of the family business can be successfully passed down to the second generation, and no more than $10 \%$ passed down to the third generation. Only about $5 \%$ of Taiwanese family businesses have a succession plan, far below the global average of $16 \%$, meaning that most Taiwanese companies face succession problems, leading to family split-ups, crises, corporate recession and even early termination of business operations.

Based on the existing literature on family business, starting from the theory of family business succession, using grounded theory, we conducted field interviews to uncover and code the key factors affecting succession. We interviewed Taiwanese entrepreneurs enrolled in a business inheritance training class to explore the considerations and implications of the succession. Finally, this work not only carries out an analysis of family business transmission and inheritance, but also analyzes the influence of key decision factors and related improvement strategy through multi-criteria decision-making methods.

The results show that the considerations for succession of authority in the family business are multi-dimensional, requiring a complex decision-making process. Among the key considerations, corporate characteristics, family capital and niche inheritance are the keys to family inheritance. Without these important factors, the outcome of the succession will be doomed to failure. In addition, the relationships of family affection and the trust and commitment of both the predecessor and successor are important factors that cannot be ignored, especially in a rapidly changing competitive market environment. With a correct understanding of the company's environmental factors and future development needs, family business practices can also be aligned with the family's business traditions and advantages, through the construction of the appropriate strategies and plans for succession [20]. By making the correct succession arrangements, the family business can finally ensure continued and sustainable development.

Certainly, this study has some limitations. First, only five facets are included, and the variables of interest are viewed from the perspective of Taiwan. Therefore, the scope of research can be expanded in future to include additional factors such as the sustainability of the family business and long-term orientation. Moreover, due to cultural differences, the criteria may not be generalizable or extendable to other countries. In addition, other studies combining and using different MADMs can provide insight into the considerations of family business heritage not found in this study. Future research can use different methodologies, such as longitudinal studies, to study this issue from different perspectives.

Supplementary Materials: The following are available online at http:/ /www.mdpi.com/2071-1050/10/10/3656/s1.

Author Contributions: J.Y.L. proposed the ideas, collected and analyzed the data and wrote the paper.

Funding: This research received no external funding.

Acknowledgments: The author is extremely grateful to the Sustainability Journal Editorial Team and reviewers who provided valuable comments for improving the quality of this article.

Conflicts of Interest: The authors declare no conflict of interest.

\section{References}

1. Oudah, M.; Jabeen, F.; Dixon, C. Determinants Linked to Family Business Sustainability in the UAE: An AHP Approach. Sustainability 2018, 10, 246. [CrossRef]

2. Chrisman, J.J.; Chua, J.H.; Sharma, P. Important attributes of successors in family businesses: An exploratory study. Fam. Bus. Rev. 1998, 11, 19-34. [CrossRef]

3. DeMassis, A.; Chua, J.; Chrisman, J. Factors preventing intra-family succession. Fam. Bus. Rev. 2008, 21, 183-199. [CrossRef]

4. Dumas, C.A. Preparing the new CEO: Managing the father-daughter succession process in family businesses. Fam. Bus. Rev. 1990, 3, 169-181. [CrossRef] 
5. Beckhard, R.; Dyer, W.G. Managing Change in the Family Firm-Issues and Strategies. Sloan Manag. Rev. 1983, 22, 59-65.

6. Molly, V.; Laveren, E.; Deloof, M. Family business succession and its impact on financial structure and performance. Fam. Bus. Rev. 2010, 23, 131-147. [CrossRef]

7. Hamrouni, A.D.; Mnasser, K. Basics factors of success in family-owned businesses from second to third generation. Int. J. Entrep. Small Bus. 2013, 18, 57-78. [CrossRef]

8. Stavrou, E.T. A four factor model: A guide to planning next generation involvement in the family firm. Fam. Bus. Rev. 1998, 11, 135-142. [CrossRef]

9. Astrachan, J.; Klein, S.; Smyrnios, K. The F-PEC scale of family influence: A proposal for solving the family business definition problem. Fam. Bus. Rev. 2002, 15, 45-58. [CrossRef]

10. Handler, W.C. Succession in family firms: A mutual role adjustment between entrepreneur and next-generation family members. Entrep. Theory Pract. 1990, 15, 37-51. [CrossRef]

11. Longenecker, J.G.; Schoen, J.E. Management succession in the family business. J. Small Bus. Manag. 1979, 16, $1-6$.

12. Núñez-Cacho, P.; Molina-Moreno, V.; Corpas-Iglesias, F.A.; Cortés-García, F.J. Family Businesses Transitioning to a Circular Economy Model: The Case of "Mercadona". Sustainability 2018, 10, 537. [CrossRef]

13. Le Breton-Miller, I.; Miller, D.; Steier, L.P. Toward an integrative model of effective FOB succession. Entrep. Theory Pract. 2004, 28, 305-328. [CrossRef]

14. Lansberg, I.; Astrachan, J.H. Influence of family relationships on succession planning and training: The importance of mediating factors. Fam. Bus. Rev. 1994, 7, 39-59. [CrossRef]

15. Dyer, W.G. Cultural Change in Family Firms; Jossey-Bass: San Francisco, CA, USA, 1986.

16. Churchill, N.C.; Hatten, K.J. Non-Market-Based Transfers of Wealth and Power: A Research Framework for Family Businesses. Am. J. Small Bus. 1987, 11, 51-64. [CrossRef]

17. O'Leary, S.; Swaffin-Smith, C. Organic Model to Reflect the Transitional Nature of Family Firms; Regent's Working Papers in Business \& Management, Working Paper 1501: RWPBM1501; REGENT'S University: London, UK, 2015.

18. Gersick, K.E.; Lansberg, I.; Desjardins, M.; Dunn, B. Stages and transitions: Managing change in the family business. Fam. Bus. Rev. 1999, 12, 287-297. [CrossRef]

19. Ramadani, V.; Bexheti, A.; Rexhepi, G.; Ratten, V.; Ibraimi, S. Succession issues in Albanian family businesses: An exploratory research. J. Balk. Near East. Stud. 2017, 19, 294-312. [CrossRef]

20. Mayer, R.; Davis, J.; Schoorman, D. An integrative model of organizational trust. Acad. Manag. Rev. 1995, 20, 709-734. [CrossRef]

21. Matthews, C.H.; Moore, T.W.; Fialko, A.S. Succession in the family firm: A cognitive categorization perspective. Fam. Bus. Rev. 1999, 12, 159-170. [CrossRef]

22. Barach, J.A.; Gantisky, J.; Carson, J.A.; Doochin, B.A. Entry of the next generation: Strategic challenge for family business. J. Small Bus. Manag. 1988, 26, 49-56.

23. Evert, R.E.; Martin, J.A.; McLeod, M.; Payne, G.T. Empirics in family business research: Progress, challenges, and the path ahead. Fam. Bus. Rev. 2016, 29, 17-43. [CrossRef]

24. Holt, D.T.; Madison, K.; Kellermanns, F.W. Variance in family members' assessments: The importance of dispersion modeling in family firm research. Fam. Bus. Rev. 2017, 30, 61-83. [CrossRef]

25. Schein, E.H. The role of the founder in creating organizational culture. Organ. Dyn. 1983, 12, 13-28. [CrossRef]

26. Olson, P.D.; Zuiker, V.S.; Danes, S.M.; Stafford, K.; Heck, R.K.Z.; Duncan, K.A. The impact of the family and business on family business sustainability. J. Bus. Ventur. 2003, 18, 639-666. [CrossRef]

27. Anglin, A.H.; Reid, S.W.; Short, J.C.; Zachary, M.A.; Rutherford, M.W. An archival approach to measuring family influence: An organizational identity perspective. Fam. Bus. Rev. 2017, 30, 19-36. [CrossRef]

28. Handler, W. Succession in family business: A review of the research. Fam. Bus. Rev. 1994, 7, 273-286. [CrossRef]

29. Barach, J.A.; Ganitsky, J.B. Successful succession in family business. Fam. Bus. Rev. 1995, 8, 131-155. [CrossRef]

30. Denis, D.J.; Denis, D.K.; Sarin, A. Ownership structure and top executive turnover. J. Financ. Econ. 1997, 45, 193-221. [CrossRef]

31. Madison, K.; Holt, D.T.; Kellermanns, F.W.; Ranft, A. Viewing family firm behavior and governance through the lens of agency and stewardship theories. Fam. Bus. Rev. 2015, 28, 312-331. [CrossRef] 
32. Chirico, F.; Nordqvist, M. Dynamic capabilities and trans-generational value creation in family firms: The role of organizational culture. Int. Small Bus. J. 2010, 28, 487-504. [CrossRef]

33. Kelly, L.M.; Athanassiou, N.; Crittenden, W.F. Founder centrality and strategic behavior in family-owned firm. Entrep. Theory Pract. 2000, 25, 27-42. [CrossRef]

34. Kotlar, J.; De Massis, A. Goal setting in family firms: Goal diversity, social interactions, and collective commitment to family-centered goals. Entrep. Theory Pract. 2013, 37, 1263-1288. [CrossRef]

35. Cabrera-Suarez, K. Leadership transfer and the successor's development in the family firm. Leadersh. Q. 2005, 16, 71-96. [CrossRef]

36. Boyne, G.A.; James, O.; John, P.; Petrovsky, N. Leadership succession and organizational success: When do chief executives make a difference? Public Money Manag. 2011, 31, 339-346. [CrossRef]

37. Sharma, P.; Chrisman, J.J.; Pablo, A.L.; Chua, J.H. Determinants of initial satisfaction with the succession process in family firms: A conceptual model. Entrep. Theory Pract. 2001, 25, 17-35. [CrossRef]

38. Cater, J.J.; Kidwell, R.E.; Camp, K.M. Successor team dynamics in family firms. Fam. Bus. Rev. 2016, 29, 301-326. [CrossRef]

39. Chrisman, J.J.; Sharma, P.; Taggar, S. Family influences on firms: An introduction. J. Bus. Res. 2007, 60, 1005-1011. [CrossRef]

40. Ali, Z.; Sun, H.; Ali, M. The Impact of Managerial and Adaptive Capabilities to Stimulate Organizational Innovation in SMEs: A Complementary PLS-SEM Approach. Sustainability 2017, 9, 2157. [CrossRef]

41. Sardeshimukh, S.; Corbett, A. The duality of internal and external development of successors: Opportunity recognition in family firms. Fam. Bus. Rev. 2011, 24, 111-125. [CrossRef]

42. McGivern, C. The dynamics of management succession: A model of chief executive succession in the small family firm. Manag. Decis. 1978, 16, 32-42. [CrossRef]

43. Feltham, T.S.; Feltham, G.; Barnett, J.J. The dependence of family businesses on a single decision-maker. J. Small Bus. Manag. 2005, 43, 1-15. [CrossRef]

44. Stanley, L.J.; Kellermanns, F.W.; Zellweger, T. Latent profile analysis: Understanding family firm profiles. Fam. Bus. Rev. 2017, 30, 84-102. [CrossRef]

45. Daspit, J.J.; Holt, D.T.; Chrisman, J.J.; Long, R.G. Examining family firm succession from a social exchange perspective. Fam. Bus. Rev. 2016, 29, 44-64. [CrossRef]

46. Danes, S.M.; Stafford, K.; Haynes, G.; Amarapurkar, S. Family capital of family firms bridging human, social, and financial capital. Fam. Bus. Rev. 2009, 22, 199-215. [CrossRef]

47. Ahn, S.Y. Founder Succession, The Imprint of Founders' Legacies, and Long-Term Corporate Survival. Sustainability 2018, 10, 1485. [CrossRef]

48. Cadieux, I. Succession in small and medium-sized family businesses: Toward a typology of predecessor roles during and after instatement of the successor. Fam. Bus. Rev. 2007, 20, 95-109. [CrossRef]

49. Dyer, W.G.; Handler, W. Entrepreneurship and family business: Exploring the connection. Entrep. Theory Pract. 1994, 19, 71-83. [CrossRef]

50. Sharma, P.; Irving, G. Four bases of family business successor commitment: Antecedents and consequences. Entrep. Theory Pract. 2005, 29, 13-33. [CrossRef]

51. Datta, D.K.; Guthrie, J.P. Executive succession: Organizational antecedents of CEO characteristics. Strat. Manag. J. 1994, 15, 569-577. [CrossRef]

52. Corbin, J.; Strauss, A. Grounded Theory Research: Procedures, Canons, and Evaluative Criteria. Qual. Sociol. 1990, 13, 3-21. [CrossRef]

53. Saaty, T.L. Theory and Applications of the Analytic Network Process; RWS Publications: Pittsburgh, PA, USA, 2005.

54. Liu, J.Y. An internal control system that includes corporate social responsibility for social sustainability in the new era. Sustainability 2018, 10, 3382. [CrossRef]

55. Tsai, W.H.; Chou, W.C.; Hsu, W. The sustainability balanced scorecard as a framework for selecting socially responsible investment: An effective MCDM model. J. Oper. Res. Soc. 2009, 60, 1396-1410. [CrossRef]

56. Hu, K.H.; Lin, S.J.; Liu, J.Y.; Chen, F.H. The Influences of CSR's Multi-dimensional Characteristics on Firm Value Determination by a Fusion Approach. Sustainability 2018, in press.

57. Opricovic, S.; Tzeng, G.H. Extended VIKOR method in comparison with outranking methods. Eur. J. Oper. Res. 2007, 178, 514-529. [CrossRef] 
58. Davis, P.; Harveston, P.D. The influence of family on the family business succession process: A multi-generational perspective. Entrep. Theory Pract. 1998, 22, 31-53. [CrossRef]

59. Madjid, T.; Debora, D.C.; Francisco, J.S.A. An extended stochastic VIKOR model with decision maker's attitude towards risk. Inf. Sci. 2018, 432, 301-318. 